\section{Exertional sickling: questions and controversy}

\author{
Morey A. Blinder, ${ }^{1}$ Sarah Russel ${ }^{2}$ \\ 1Departments of Medicine and Pathology \\ and Immunology, Washington University, \\ St. Louis, MO; ${ }^{2}$ University of Notre \\ Dame, Notre Dame, IN, USA
}

\section{Abstract}

Sickle cell trait (SCT) occurs in about $8 \%$ of African-Americans and is often described to be of little clinical consequence. Over time, a number of risks have emerged, and among these are rare but catastrophic episodes of sudden death in athletes and other individuals associated with physical activities which is often described as exercise collapse associated with sickle trait (ECAST). Despite an epidemiologic link between SCT and sudden death as well as numerous case reports in both medical literature and lay press, no clear understanding of the key pathophysiologic events has been identified. Strategies for identification of individuals at risk and prevention of ECAST have been both elusive and controversial. Stakeholders have advocated for different approaches to this issue particularly with regard to screening for hemoglobin $\mathrm{S}$. Furthermore, the recommendations and guidelines that are in place for the early recognition of ECAST and the prevention and treatment of the illness are not well defined and remain fragmented. Among the cases identified, those in collegiate football players in the United States are often highlighted. This manuscript examines these case studies and the current recommendations to identify areas of consensus and controversy regarding recommendations for prevention, recognition and treatment of ECAST.

\section{Introduction}

Mutations in the alpha and beta globin genes of hemoglobin (Hgb) frequently occur. Among the most commonly encountered worldwide is the $\beta_{6} \mathrm{Glu} \rightarrow$ Val substitution defining Hgb S. In sickle cell disease both beta globin genes are affected while in sickle cell trait (SCT) one normal and one mutated beta globin gene result in a pancellular distribution of Hgb $S$ accounting for about $40 \%$ of the total Hgb. A number of studies have found the prevalence of SCT in the African-American population to be about 7-8\%, but it is also identified in persons of other ethnic backgrounds at a lower frequency translating into about 3 million affected individuals in the United States and 300 million worldwide. ${ }^{1}$ A study of US military personnel similarly showed that $7.8 \%$ of black recruits had SCT suggesting that there is no apparent selection against enrollment in the military service. ${ }^{2}$ The incidence of SCT in athletes is not well defined although its prevalence in black football players in the National Football League was 39/579 (6.7\%) similar to that in the general population. ${ }^{3}$

Studies on the physiologic effects of exertion have long established that exercise can induce a metabolic acidosis. ${ }^{4,5}$ Notable among these studies is the observation that repeat exertion to exhaustion can lead to extreme acidosis, and this exercise pattern is similar to some currently used regimens of athletic training. ${ }^{4}$ In patients with sickle cell disease, triggers for vaso-occlusion include acidosis, dehydration and hypoxia, raising the suspicion that extreme exertion may be sufficient under certain circumstances to trigger similar complications in individuals with SCT. Additional in vitro data indicates that red blood cells (RBCs) from SCT individuals may become irreversibly sickled at a $\mathrm{PO}_{2}$ of $\sim 25 \mathrm{mmHg}$, and this effect is enhanced by acidosis. ${ }^{6}$ This is confirmed by studies in SCT individuals that showed venous sickling at low oxygen tension. ${ }^{7}$ Subsequently a small study comparing individuals with and without SCT who underwent intensive exercise showed that a small percentage of irreversibly sickled cells could be identified in all the individuals with SCT but none of those without Hgb S. ${ }^{8}$ No untoward clinical effects were identified, but this raises the concern that under some conditions, extensive formation of irreversibly sickled cells may occur that lead to clinical consequences. In addition to hypoxia and acidosis, other conditions that may trigger such events have also been suspected including increased core body temperature, ambient heat index, blood viscosity, dehydration, inflammation and oxidative stress, but the relative role of each of these factors is not fully defined. ${ }^{9-11}$ On the other hand, some studies have failed to show a clear physiologic effect from SCT on exercise even under some stressful conditions. ${ }^{12}$ The consequence has been that when fatalities have occurred in individuals with SCT, they are perceived as rare and unpredictable events. However, in 1987, the seminal study by Kark and associates found non-traumatic sudden death in black military recruits to be 32 fold higher than in individuals identified as non-black. Among black recruits, the relative risk of sudden unexplained death was 27.6 fold higher in the individuals with SCT, thus providing clear epidemiologic evidence that the presence of Hgb $S$ contributed to these deaths. ${ }^{2}$ Harmon and colleagues have also reported a 37 -fold greater risk of exertion-related death in Division 1 col-
Correspondence: Morey A. Blinder, Department of Internal Medicine and Pathology and Immunology, Division of Hematology, Campus Box 8125, Washington University School of Medicine, 660 South Euclid Avenue, St. Louis, M0 63110, USA. Tel.: +1.314.362.8814 - Fax: +1.314.362.8813.

E-mail: mblinder@dom.wustl.edu

Key words: sickle cell trait, exercise collapse, sudden death.

Acknowledgments: the authors would like to thank Dr. Douglas Tollefsen, who provided helpful suggestions for the manuscript.

Contributions: the authors contributed equally.

Conflict of interests: the authors declare no potential conflict of interests.

Received for publication: 31 May 2014.

Revision received: 10 September 2014.

Accepted for publication: 17 September 2014.

This work is licensed under a Creative Commons Attribution NonCommercial 3.0 License (CC BYNC 3.0).

(C)Copyright M.A. Blinder and S. Russel, 2014

Licensee PAGEPress, Italy

Hematology Reports 2014; 6:5502

doi:10.4081/hr.2014.5502

lege football in individuals with SCT. ${ }^{13}$ Recently, a summit on SCT composed of military, athletic and medical experts tried to identify clinical guidelines for this problem and have termed these events as exercise collapse associated with sickle trait (ECAST). ${ }^{14}$ The purpose of this manuscript is to evaluate the reported cases of sudden death in college football players related to SCT and to examine current recommendations for prevention and treatment of ECAST.

\section{Materials and Methods}

Data searches were performed of both medical literature and lay press to identify cases of potential ECAST. Once cases were identified, these were limited to lethal events within 48 hours among American college football players from 2000-2010, for these patients had less variation in their physical fitness than the general population. Physical data was collected including age, height and weight. Circumstances surrounding their deaths were noted, including activities prior to the collapse and climate conditions at the time of these events.

Recommendations regarding SCT among professional organizations involved in either hematology or sports medicine were identified 
as described in the most recent stances published on their websites. Their positions on universal screening for SCT were identified, and their recommendations on prevention, detection, and treatment of ECAST were also recorded.

\section{Results}

Table 1 summarizes the SCT related deaths that occurred in college football between 2000 2010. ${ }^{15-24}$ While each case is unique, they share many characteristics, such as the athletes or their coaches encouraging the participants despite evolving symptoms of ECAST. All occurred during intense conditioning including serial sprints and/or agility training. Many experienced unusual cramps, muscle weakness, extreme fatigue, and even a first collapse before slumping to the ground for their last time. In one reported instance, the athlete was reprimanded for his perceived weakness and neglected by trainers, and a teammate was rebuked for assisting him off the field. ${ }^{15}$ Additionally, these cases all occurred below an elevation of $645 \mathrm{~m}$ above sea level, so high alti- tude hypoxia is not necessary for ECAST to occur. $^{15-24}$ While conditions were warm and humid in some cases, the weather alone was not typical of that which places athletes at a high risk for heat-related illness. While several of the initial reports cited heat-related illness or other causes as the primary reasons for death, autopsies later revealed that sickle cells were identified and likely contributed to the athletes' death. Although a personal or family history of SCT was available in some cases, in no case was SCT suspected as the cause of the collapse, so there was no clear medical intervention or focused treatment.

Table 2 shows the positions of various health and sports organizations on screening, prevention and treatment of SCT. While the National Collegiate Athletic Association (NCAA) mandates the universal screening of its participants, the American Society of Hematology (ASH) is unequivocally against universal screening for SCT. Other organizations vary in their positions on screening and prevention. In the absence of strong medical evidence, these organizations provide differing recommendations on the prevention of ECAST. The National Athletic Trainers' Association (NATA) has made clear recommendations on preventative measures, and other organizations reference the NATA's guidelines. $^{25}$ These recommendations include longer rest and recovery between conditioning repetitions, exclusion from performance tests, hydration, and available supplemental $\mathrm{O}_{2}$. Other organizations highlight similar themes but vary in the details. While these guidelines are directed at athletes with SCT, some organizations, such as ASH, American Medical Society for Sports Medicine (AMSSM), and Sickle Cell Disease Association of America (SCDAA), advise using similar recommendations as universal precautions concluding that this would safeguard all athletes from heatrelated illness and other effects of overexertion. Whether this approach will prove effective in preventing ECAST is not clear and remains controversial. ${ }^{26}$ Other organizations that agreed with ASH include the American Public Health Association, Association of Public Health Laboratories, American Society of Clinical Pathology, and the American Society of Pediatric Hematology-Oncology (ASPHO), but none of these added any further recommendations. In contrast, most sports organizations do not specify these guidelines for universal precautions by all athletes, favoring a targeted approach. Few organizations provided guidelines for detecting and treating a sick-

Table 1. Cases of fatal, exercise collapse in college football players with sickle cell trait.

\begin{tabular}{|c|c|c|c|c|c|c|c|c|}
\hline Ref. & Age & $\begin{array}{l}\text { Patient } \\
\text { height/weight }\end{array}$ & Institution & $\begin{array}{l}\text { Altitude } \\
\text { (m above } \\
\text { sea level) }\end{array}$ & Year & $\begin{array}{l}\text { Ambient } \\
\text { conditions } \\
\text { temperature }\left({ }^{\circ} \mathrm{F}\right)\end{array}$ & Activities prior to collapse & Comments \\
\hline 15 & 19 & 5'11"/190 lbs & Tennessee Tech & 350 & 2000 & mid 80's & $\begin{array}{l}\text { Collapsed during sprint testing } \\
\text { on first day of conditioning }\end{array}$ & $\begin{array}{l}\text { Death initially felt } \\
\text { to be heat stroke }\end{array}$ \\
\hline 16 & 18 & 6'2"/220 lbs & Florida State & $<60$ & 2001 & Indoors, $<80$ & $\begin{array}{l}\text { Collapsed indoors during offseason } \\
\text { intense agility (mat) drills, was suffering } \\
\text { from head cold at time of collapse }\end{array}$ & $\begin{array}{l}\text { Death initially felt } \\
\text { to be cardiac } \\
\text { arrhythmia }\end{array}$ \\
\hline 17 & 18 & 5 '9"/190 lbs & Bowling Green & 167 & 2004 & $85-88$ & $\begin{array}{c}\text { Collapsed with unusual leg cramps } \\
\text { while running serial sprints known as gassers }\end{array}$ & \\
\hline 18 & 19 & 6'3"/220 lbs & Missouri & 230 & 2005 & 85 & $\begin{array}{l}\text { Poor performance about } 45 \text { min into } \\
\text { conditioning, complained of blurry vision } \\
\text { but was forced to repeat the drills }\end{array}$ & $\begin{array}{l}\text { Death initially } \\
\text { attributed to viral } \\
\text { meningitis }\end{array}$ \\
\hline 19 & 19 & 5 '9"/190 lbs & Rice & 38 & 2006 & Warm afternoon & $\begin{array}{l}\text { Struggled through conditioning, breathing } \\
\text { heavily and complaining of leg cramping, } \\
\text { collapsed after his sixteenth } 100 \text { m dash }\end{array}$ & \\
\hline 20 & 19 & 5'10"/181 lbs & Central Florida & 29 & 2008 & Indoors & $\begin{array}{l}\text { Second workout after spring break, struggled } \\
\text { through an obstacle course after completing } \\
\text { a weightlifting session, was breathing heavily } \\
\text { with muscle weakness, coach singled athlete } \\
\text { out for lack of effort, collapsed at end of practice }\end{array}$ & \\
\hline 21,22 & 22 & 6'3"/260 lbs & N. Carolina A\&T & 272 & 2008 & & $\begin{array}{l}\text { Complained of dizziness after running sprints } \\
\text { for conditioning, loss of consciousness } \\
\text { in the training room after practice }\end{array}$ & $\begin{array}{l}\text { Death initially } \\
\text { attributed to heat } \\
\text { related illness }\end{array}$ \\
\hline 23 & 20 & $5 ' 10 " / 185 \mathrm{lbs}$ & Western Carolina & 645 & 2009 & & $\begin{array}{l}\text { Complained of leg cramps during offseason } \\
\text { conditioning drills, loss of consciousness }\end{array}$ & $\begin{array}{l}\text { Enlarged heart } \\
\text { in autopsy }\end{array}$ \\
\hline 24 & 20 & 5'9"/186 lbs & Mississippi & 154 & 2010 & & $\begin{array}{l}\text { Collapsed after first agility drill but was } \\
\text { encouraged to continue, collapsed after second } \\
\text { station and was allowed to rest, prior to collapse } \\
\text { trainers began to provide aid, transported to the } \\
\text { hospital near the end of practice }\end{array}$ & \\
\hline
\end{tabular}


ling-related collapse, but those who did generally support the NATA's policy in these areas.

\section{Discussion}

\section{Fatal exertional sickling}

Sickle cell trait as a cause of sudden death in athletes was first noted in 1974 with the death of an American collegiate football player. ${ }^{26}$ Since that time there have been a number of widely publicized cases in the nonscientific literature. Most of these have involved college football players rather than younger students or older professional athletes, and the reasons for this are not clear although the widespread public interest in college football may explain this in part. While fitness levels could potentially affect the athlete's likelihood of ECAST since these deaths occurred during pre-season conditioning, these athletes were generally recognized to be in excellent physical condition. Nevertheless, improved conditioning may modulate several biological factors, notably inflammation and oxidative stress. ${ }^{10,11}$ In accord with the known pathophysiology, it seems more likely that a decrease in venous $\mathrm{PO}_{2}$ in concert with acidosis occurring during extreme exertion were major contributors. While it is conceivable that the presence of sickled RBCs occurred post- mortem, the clear epidemiologic evidence linking SCT to sudden death is a compelling argument for a direct causal effect. ${ }^{2,13}$

At present in the United States, it is likely that almost all high school aged students and an increasing number of older athletes have already been tested for $\mathrm{Hgb} \mathrm{S}$ as part of newborn screening. Adopted as a guideline by the National Institutes of Health for all individuals in 1987, hemoglobinopathy testing became incorporated into newborn screening programs in all states by 2006, so sickle cell status should be available for all children and adolescents born after that time. ${ }^{27}$ Despite this, the prevalence of SCT in athletes participating in organized sports is generally unknown. In the case of college football, ethnicity data collected on players in the NCAA over the span from 2000-2010 shows an increase in participation by AfricanAmericans from 16,200 participants (28.1\%) to $22,892(34.5 \%) .^{28}$ Assuming a prevalence of SCT of $7 \%$, this would indicate that there are currently $\sim 1600$ athletes playing NCAA football who are at risk. Based on the recent reported deaths of about one athlete with SCT every 1-2 years described in Table 1, this would suggest the estimated risk of death from ECAST to be 26$51 / 100,000 / 100,000$ participants. By comparison, calculations for fatal traumatic injuries in any college football player is $0.45 / 100,000$ and the risk for other non-traumatic death is 2.1/100,000. ${ }^{29}$ An analysis of all NCAA Division I athletes in all sports estimated over 2,000 participants with SCT and predicts about 7 deaths over a 10 year period consistent with the current review. ${ }^{30}$

Just as identifying the key pathophysiologic triggers for ECAST has proven to be difficult, determining the risk of SCT remains a vexing problem. For example, if the prevalence of SCT in football players is lower than in the general population, then the relative risk would be significantly higher than estimated. In addition, if other non-fatal complications such as heat stroke can be attributed at least in part to SCT, then serious but non-fatal complications could be significantly higher than assumed. On the other hand, if deaths attributed to SCT are overestimated, then the relative risk may be lower. Better defining the population at risk for ECAST and other sickle cell related complications by identifying individuals with $\mathrm{Hgb} \mathrm{S}$ would seem to be a prerequisite to studying the natural history and clinical consequences of SCT. According to ClinicalTrials.gov, at least one such effort along these lines is underway by collecting self-reported health data in current or former high school or college football players with SCT. ${ }^{31}$

\section{Screening, prevention and treatment}

In the absence of a clear understanding of both the inciting pathophysiology and the identification of individuals at risk of ECAST, a num-

Table 2. Summary of guidelines for sickle cell trait screening and prevention, detection, and treatment of exertional sickling.

\begin{tabular}{|c|c|c|}
\hline Organization & Sickle cell trait screening & Recommendations for prevention \\
\hline $\begin{array}{l}\text { National Collegiate Athletic } \\
\text { Association }\end{array}$ & $\begin{array}{l}\text { Mandate universal screening } \\
\text { in all sports to participate }\end{array}$ & Similar to NATA recommendations \\
\hline $\begin{array}{l}\text { National Athletic Trainers } \\
\text { Association }^{21}\end{array}$ & Supports universal screening & $\begin{array}{l}\text { Set their own pace; increase intensity in a paced progression, and rest longer } \\
\text { between repetitions; participate in preseason conditioning; programs; } \\
\text { excluded from certain tests such as mile runs and serial sprints; stop activity when } \\
\text { experiencing symptoms of rhabdomyolysis; do not exercise if ill; adjust activity } \\
\text { accordingly in extreme heat, at altitude, with dehydration, and with asthma; } \\
\text { be able to recognize symptoms of sickling }\end{array}$ \\
\hline $\begin{array}{l}\text { American College of Sports } \\
\text { Medicine (ACSM) }\end{array}$ & $\begin{array}{l}\text { Supports universal screening; } \\
\text { Genetic counseling for abnormal results }\end{array}$ & $\begin{array}{l}\text { Encourages team physicians and athletic trainers to become familiar with } \\
\text { SCT concerns and symptoms of sickling; Shouldn't be restricted from activity }\end{array}$ \\
\hline $\begin{array}{l}\text { American Medical Society } \\
\text { for Sports Medicine (AMSSM) }\end{array}$ & Approves NCAA's policy & Supports ASH in pursuit of universal precautions that make sports safer for all \\
\hline $\begin{array}{l}\text { College of American } \\
\text { Pathologists (CAP) }\end{array}$ & Supports universal screening & Take precautions similar to those recommended by NATA \\
\hline $\begin{array}{l}\text { American Society of } \\
\text { Hematology (ASH) }\end{array}$ & Against universal screening & Recommends use of universal precautions \\
\hline $\begin{array}{l}\text { Sickle Cell Disease Association } \\
\text { of America (SCDAA) }\end{array}$ & $\begin{array}{l}\text { Promotes voluntary screening, } \\
\text { but is against universal screening }\end{array}$ & Implement universal precautions \\
\hline $\begin{array}{l}\text { National Federation of State } \\
\text { High School Associations (NFHS) }\end{array}$ & Recommended, not required & See NATA consensus statement \\
\hline $\begin{array}{l}\text { American Orthopedic Society } \\
\text { of Sports Medicine (AOSSM) }\end{array}$ & Recommended, not required & See NATA consensus statement \\
\hline $\begin{array}{l}\text { Centers for Disease Control } \\
\text { (CDC) }\end{array}$ & No recommendations & $\begin{array}{c}\text { Set their own pace; rest often between rounds in drills; } \\
\text { stay hydrated throughout exercise; avoid overheating by misting athletes } \\
\text { with water or going into air conditioning during breaks; promptly seek medical } \\
\text { attention when feeling ill }\end{array}$ \\
\hline
\end{tabular}


ber of organizations involved in the direct care of athletes and military service personnel have provided guidelines on the screening for SCT and, in a few cases, recommendations for prevention, recognition, and treatment of ECAST (Table 2). Most contentious among these recommendations has been whether or not to employ universal screening to identify individuals with SCT. A number of organizations have advocated for universal screening, and most notably the NCAA has incrementally implemented universal sickle cell screening by mandating either current testing, evidence of previous testing, or a signed waiver deferring legal liability for athletes to participate. This policy was initiated to identify participants at risk so that coaches, trainers and staff are aware of these individuals and can implement preventative measures and early treatment against ECAST. Additionally, this policy was driven in part by the litigation that arose from the unexpected death of an individual who was unaware of his sickle cell status. ${ }^{19}$ When the NCAA policy was implemented, a survey indicated that only about $22 \%$ of responding institutions screened all athletes, but this is likely to have increased significantly over time. ${ }^{32}$ In contrast to the NCAA, ASH set forth a position paper in 2012 outlining the case against universal screening, including the maintenance of privacy of personal health information for those athletes. Arguments against universal screening are numerous and have been highlighted by Bonham et al. ${ }^{33}$ These include the cost and reliability of testing. However, screening can be completed with one of several commercially available blood tests at a cost of $\$ 3.00-4.00 /$ sample with high reliability, and additional confirmatory testing such as high performance liquid chromatography (HPLC) analysis could be offered to individuals identified to have a sickling Hgb. Another concern is whether the knowledge of SCT status will jeopardize the playing career or lead to prejudicial judgments regarding participation in any activity. This has been noted in the past when SCT individuals were excluded from certain military occupations. ${ }^{34}$ More recently, we identified scant evidence that military personnel or competitive athletes who have SCT are excluded from their respective activities. Some organizations remain concerned that screening would violate the athlete's privacy and lead to discrimination. ${ }^{33}$ Other ongoing concerns regarding a universal screening policy include a lack of genetic counseling for affected individuals. Furthermore, while the US Army has abolished universal screening in favor of universal precautions, the US Marine Corps continues to test all recruits. ${ }^{35}$

Less often discussed but of considerable importance are specific recommendations for prevention, detection, and treatment of ECAST. Recommendations for prevention have been made by a number of organizations and have common themes although vary in their details.
Whether universal precautions against sickling for all participants or some form of targeted prevention for individuals with confirmed SCT is the most effective is not defined. The NATA published a consensus statement with recommendations regarding prevention of sudden death in sports, especially with environmental stress. ${ }^{25}$ Of note, NATA has suggested a framework to distinguish between a sickling-related collapse and other diagnoses so that athletes and staff could recognize the issue and respond to it appropriately. The SCDAA, AOSSM, NFHS, and NCAA have referenced NATA's information on the detection of ECAST. Additionally, Eichner has recently described features of a SCT associated collapse along with prevention and treatment suggestions. ${ }^{36}$ Based on the anecdotal data, it seems reasonable that all coaches, trainers and players involved in sports at risk should be familiar with prevention guidelines and their potential for implementation. By increasing staff and player education about SCT, it is reasonable to conclude that most cases of ECAST and its consequences are preventable.

Optimal treatment of ECAST is undefined and is usually a medical emergency that falls to first responders rather than to hematologists or others with expertise in sickle cell disease. Only a few organizations have published treatment recommendations, and there are no welldesigned studies in the medical literature describing successful (or unsuccessful) approaches. While many organizations have overlapping ideas on how to manage ECAST, their suggestions and opinions vary and fail to provide consistent advice for those caring for athletes or others who might be at risk. No approach has been tested in a clinical study. Rare cases have been reported in which athletes initially diagnosed with heat stroke were subsequently identified as having ECAST and recovered. ${ }^{37}$ Among the organizations providing recommendations regarding ECAST, one common theme arises: athletes and military personnel should not be barred or limited in opportunities because they have SCT. Since these organizations all support the success of athletes with SCT, an agreed upon set of guidelines for coaches, trainers, athletes and medical personnel to follow in order to maintain player safety should be a priority.

While the issue of ECAST has been raised most frequently in the setting of military service and competitive athletics, sudden death in individuals with SCT has been noted in other circumstances of strenuous activity including firefighter training and altercations with law enforcement. ${ }^{38}$ While screening and prevention may be possible in some of these circumstances, this may not always be the case, and rapid recognition of the illness and proper emergent treatment remain key issues.

We believe that the lack of a consensus on the approach to ECAST poses an opportunity for additional research in both the understanding of the pathophysiology and of the risks linked to SCT, as well as the clinical approach to prevention, diagnosis and treatment of ECAST. The lack of understanding of who may be at risk hinders further clinical studies, so screening for research purposes could prove beneficial. Whether or not milder forms of clinically significant ECAST exist and are preventable or treatable might become apparent and, if present, may also lead to the identification of biomarkers for people at risk. The possible relationship to heat-related illness, rhabdomyolysis, and other abnormalities such as glucose-6-phosphate dehydrogenase (G6PD) deficiency remains to be defined. Furthermore, a well-conceived approach to ECAST including recognition and treatment in other settings beyond the military and athletics needs to be delineated.

\section{Conclusions}

Compared to some other medical subspecialties, the role of the hematologist in sports medicine has been modest. In addition to the understanding of ECAST in competitive athletics, it is also important for hematologists to take a leadership role in other areas of sports medicine in which hematologic issues arise. Examples of these include the study of the risk, prevention and treatment of bleeding in casual or competitive athletes with hemophilia or on anticoagulants and the study of the role of iron supplementation in optimizing athletic performance. This, along with determining guidelines for the prevention, detection, and treatment of ECAST, allows more athletes to participate safely in sports without otherwise benign blood conditions hindering their participation.

\section{References}

1. Grant AM, Parker CS, Jordan LB, et al. Public health implications of sickle cell trait: a report of the CDC meeting. Am J Prev Med 2011;41:S435-9.

2. Kark JA, Posey DM, Schumacher HR, Ruehle CJ. Sickle-cell trait as a risk factor for sudden death in physical training. $\mathrm{N}$ Engl J Med 1987;317:781-7.

3. Murphy JR. Sickle cell hemoglobin (Hb AS) in black football players. JAMA 1973; 225:981-2.

4. Hermansen L, Osnes JB. Blood and muscle $\mathrm{pH}$ after maximal exercise in man. J Appl Physiol 1972;32:304-8.

5. Karlsson J. Lactate in working muscles after prolonged exercise. Acta Physiol 
Scand 1971;82:123-30.

6. Lange RD, Minnich V, Moore CV. Effect of oxygen tension and of $\mathrm{pH}$ on the sickling and mechanical fragility of erythrocytes from patients with sickle cell anemia and the sickle cell trait. J Lab Clin Med 1951; 37:789-802.

7. Martin TW, Weisman IM, Zeballos RJ, Stephenson SR. Exercise and hypoxia increase sickling in venous blood from an exercising limb in individuals with sickle cell trait. Am J Med 1989;87:48-56.

8. Ramírez A. Morphological features of red blood cells in subjects with sickle cell trait. Arch Intern Med 1976;136:1064.

9. Tripette J, Loko G, Samb A, et al. Effects of hydration and dehydration on blood rheology in sickle cell trait carriers during exercise. Am J Physiol Heart Circ Physiol 2010; 299:H908-14.

10. Aufradet E, Monchainin G, OyonnoEngelle S, et al. Habitual physical activity and endothelial activation in sickle cell trait carriers. Med Sci Sports Exerc 2010; 42:1987-94.

11. Chirico EN, Martin C, Faes C, et. al. Exercies trainiing blunts oxicative stress in sickle cell trait carriers. J Appl Physiol 2012;112:1445-53.

12. Weisman IM, Zeballos RJ, Johnson BD. Cardiopulmonary and gas exchange responses to acute strenuous exercise at 1,270 meters in sickle cell trait. Am J Med 1988;84:377-83.

13. Harmon KG, Drezner JA, Casa DJ. To screen or not to screen for sickle cell trait in American football. Br $\mathrm{J}$ Sports Med 2012:46:158.

14. O'Connor FG, Bergeron MF, Cantrell J, et al. ACSM and CHAMP summit on sickle cell trait: mitigating risks for warfrighters and athletes Med Sci Sports Exerc 2012;44:2045-56.

15. Tennessee Tech University. Campus Mourns the Death of Student-Athlete Preston Birdsong. Tennessee Tech University. 2000. Available from: http:/ /www.tntech.edu/pressreleases/campus- mourns-the-death-of-student-athlete-preston-birdsong/

16. Associated Press. Florida State releases report. ESPNcom. 2002. Available from: http://espn.go.com/abcsports/bcs/s/2001/04 20/1176186.html

17. Markey M. BGSU football player dies on his first day. Toledo Blade. 2004. Available from: http://www.toledoblade.com/frontpage/2004/09/16/BGSU-football-playerdies-on-his-1st-day.html

18. Associated Press. Documents show Missouri missteps in 0'Neal death. USA Today. 2009. Available from: http:/usatoday30.usatoday.com/sports/college/football/b ig12/2009-04-14-missouri-oneal_N.htm

19. Associated Press. Lawsuit settled in death of Rice football player. ESPN.com. 2009. Available from: http:/sports.espn.go.com/ ncf/news/story?id=4293675

20. Associated Press. Ex-UCF player testifies in death trial. ESPNcom. 2011. Available from: http://sports.espn.go.com/ncf/news/ story? $\mathrm{id}=6684761$

21. Associated Press. North Carolina A\&T fires official over sickle cell death. Diverse Education. 2011. Available from: http:// diverseeducation.com/article/14644/

22. Goode T. North Carolina A\&T football player dies during workout. USA Today. 2008. Available from: http://usatoday30.usatoday.com/sports/college/football/meac/200805-28-nc-at-death_N.htm

23. Staff Reports. Ja'Quayvin Smalls family files suit. Post and Courier. 2011. Available from: http://www.postandcourier.com/article/20110927/PC20/309279937

24. Dodd D. Family of deceased Ole Miss player files wrongful death suit. CBSSportscom. 2011. Available from: http:/www.cbssports. com/collegefootball/story/15073085/familyof-deceased-ole-miss-player-files-wrongfuldeath-suit

25. Casa DJ, Guskiewicz KM, Anderson SA, et al. National athletic trainers' association position statement: preventing sudden death in sports. J Athl Train 2012;47:96-118.

26. Eichner ER. Sickle cell trait. J Sport
Rehabil 2007;16:197-203.

27. Benson JM, Therrell BL. History and current status of newborn screening for hemoglobinopathies. Semin Perinatol 2010; 34:134-44.

28. Zgonc E. NCAA Student-athlete race/ethnicity report. Indianapolis: National Collegiate Athletic Association; 2010.

29. Boden BP, Breit I, Beachler JA, et al. Fatalities in high school and college football players. Am J Sports Med 2013; 41:1108-16.

30. Tarini BA, Brooks MA, Bundy DG. A policy impact analysis of the mandatory NCAA sickle cell trait screening program. Health Serv Res 2012;47:446-61.

31. Flansburg C. Sickle cell trait in football players. Available from: http://clinicaltrials.gov/show/NCT01891877

32. Jung AP, Selmon PB, Lett JL, Petrella JK. Survey of sickle cell trait screening in NCAA and NAIA institutions. Phys Sportsmed 2011;39:158-65

33. Bonham VL, Dover GJ, Brody LC. Screening student athletes for sickle cell trait-a social and clinical experiment. N Engl J Med 2010;363:997-9.

34. Rayman RB. Sickle cell trait and the aviator. Aviat Space Environ Med 1979;50:1170-2.

35. Lang I. Sickle cell and recruit training. Navy Medicine Live 2012. Available from: http://navymedicine.navylive.dodlive.mil/a rchives/3184

36. Eichner ER. Sickle cell considerations in athletes. Clin Sports Med 2011:30:537-49.

37. Upchurch J. Testing for athletes at risk. Sooner Magazine. 2010. Available from: https://www.oufoundation.org/SM2/Fall201 0/story/Testing_For_Athletes_At_Risk

38. Scheinin L, Wetli CV. Sudden death and sickle cell trait: medicolegal considerations and implications. Am J Forensic Med Pathol 2009;30:204-8. 